DOI https://doi.org/10.30929/2307-9770.2020.08.02.01

UDC [37.01/.09+378] $372(045)$

\title{
Task-Based Approach in The Frame of Professional Preparation at Universities
}

\author{
Vasylyshyna N.* \\ National aviation university, Kyiv, Ukraine
}

Received: $17.03 .2020 \quad$ Accepted: 28.05 .2020

\begin{abstract}
The success that our students can achieve in the process of language learning depends on different factors, among which students' involvement in language acquisition is considered to be one of the crucial in modern communicative methodology. While teaching foreign languages we use various methods, approaches and techniques. Language purpose influences our choice of syllabus items and teaching techniques. The task-based approach has gained popularity in the field of language teaching since the last decade of the 20fh century and significant scholars have joined the discussion and increased the amount of analytical studies on the issue. In this paper we have attempted to describe the task-based approach criticality, pointing out what we consider positive in this approach, and underlining the inadequacy of some assumptions and conclusions. It must once more be emphasized that task-based approach is useful teaching and learning pedagogical device among others available. Taking into consideration the rate of the foreign language competence importance for today's university learners, we were able to identify the main purposes of the survey that are: the first part of the paper was dedicated to figuring out real world tasks and classroom tasks as well as presents theoretical overview of task-based approach; then the second part of the paper was grounded on the description of the most common advantages and disadvantages of the task-based approach; the third part provided the steps for a successful task-based teaching activity (the pre-task; task cycle; language focus; a relevant homework assignment) and the fourth part was concerned with the reveal of types of assignments that are based on task-based teaching (information gap activities, reasoning gap activities, opinion gap activities, road trip, the business mixer, department of tourism). In conclusion we have illustrated that multiple advantages of task-based approach are dealing with: real-life communication before language analysis; it is learner-centered and meets students' needs giving them opportunity to use all possible language resources in authentic communicative situations; encourages learners' autonomy. Due to this students can analyze what they know, do not know or partially know and need to improve; they are encouraged to investigate the language. Thus students take responsibility for their progress in language learning. Also it was shown that teachers can use this approach in mixed ability classes where both weak and strong students can perform the task successfully according to their language level, with different accuracy in the same communication situation and find out their individual needs. One more outcome of the survey is that students deal with a wide range of language, because they are not restricted by syllabus demands to definite lexis, grammar or structures. It was recommended to use a combination of task-based approach and traditional approach to language learning in order to meet students' requirements best of all.
\end{abstract}

Key words: language teaching, methods, methodology, communicative skill, tasks, task based approach, advantages and disadvantages, steps, language learning.

\section{Практико-зорієнтований підхід у процесі професійної підготовки в університетах}

\section{Василишина Н. М.}

Національний авіаційний університет, Київ, Україна

\begin{abstract}
Анотація. Успіх, якого можуть досягти наші студенти в процесі вивчення мови, залежить від різних фракторів, серед яких участь учнів у оволодінні мовою вважається одним із найважливіших у сучасній комунікативній методологї. Під час викладання іноземних мов ми використовуємо різні методи, підходи та прийоми. Мовна мета впливає на наш вибір предметів навчальних програм та методики викладання. Практико-зорієнтований підхід набув популярності в галузі викладання мови з останнього десятиліття 20 століття, оскільки багато
\end{abstract}

Corresponding Author: Vasylyshyna Nataliia. Tel. +38(068)593-07-27. E-mail: filologyN@gmail.com. National aviation university, Otradnyy Av., 4, Kyiv, Ukraine, 03143.

Відnовідальний автор: Василишина Наталія Максимівна. +38(068)593-07-27. filologyN@gmail.com. Національний авіаційний університет, проспект Відрадний. 4, м. Київ, Україна, 03143. 
вчених долучилися до обговорення здійснення аналітичних досліджень з цього питання. У цій роботі ми спробували описати актуальність підходу, вказавши на те, що ми вважаємо позитивним у цьому підході, та підкресливши неадекватність деяких припущень та висновків. Слід ще раз підкреслити, що Практикозорієнтований підхід є корисним педагогічним приладом для викладання та навчання серед інших. Беручи до уваги ступінь значущості компетенції з іноземної мови для студентів університету сьогодні, ми виділили основні цілі дослідження, зокрема: перша частина статті була присвячена з'ясуванню сутності такого педагогічного явища, як «завдання», а також представила теоретичний огляд практико-зорієнтованого підходу; потім друга частина статті ґрунтувалася на описі найпоширеніших переваг та недоліків підходу; третя частина містила опис етапів успішної навчальної діяльності на основі завдань (попереднє завдання; цикл завдань; фокус на мові; відповідне домашнє завдання), а четверта частина стосувалася розкриття типів завдань практико-зорієнтованого підходу (інформаційна розбіжність, діяльність у роздумах, недоліки в думках, подорож, діловий міксер, відділ туризму). Таким чином, у ході дослідження ми проілюстрували, що численні переваги практико-зорієнтованого підходу стосуються: спілкування в реальному житті на противагу мовному аналізу; студентів та їхніх потреб, їхній можливості використовувати мовні ресурси в автентичних комунікативних ситуаціях; заохочення самостійність студентів. Завдяки цьому тідходу студенти можуть аналізувати те, що вони знають, не знають або частково знають і потребують вдосконалення; вони вмотивовані вивчати мову. Таким чином вони беруть на себе відповідальність за свій прогрес у вивченні мови. Також було показано, що вчителі можуть використовувати цей підхід у змішаних класах, де і слабкі, і сильні учні можуть успішно виконувати завдання відповідно до свого мовного рівня, з різною точністю в одній і тій же ситуації спілкування та з'ясовувати свої індивідуальні потреби. Ще одним результатом дослідження $є$ те, що студенти охоплюють широкий спектр мови, так як вони не обмежуються вимогами навчальних програм до певної лексики, граматики чи структур. Було рекомендовано використовувати поєднання практикозорієнтованого та традиційного підходів до вивчення англійської мови, щоб досягти максимальної ефективності навчального процесу..

Ключові слова: викладання мови, методи, методика, комунікативна майстерність, завдання, практикозорієнтований підхід, переваги та недоліки, етапи, вивчення мови.

\title{
Практико-ориентированный подход в процессе профессиональной подготовки в университетах
}

\section{Василишина Н. М.}

Национальный авиационный университет, Киев, Украина

\begin{abstract}
Аннотация. Успех, которого могут достичь наши студенты в процессе изучения языка, зависит от различных факторов, среди которых участие учащихся в овладении языком считается одним из важнейших в современной коммуникативной методологии. Во время преподавания иностранных языков мы используем различные методы, подходы и приемы. Языковая цель влияет на наш выбор предметов учебных программ и методики преподавания. Практически-ориентированный подход приобрел популярность в области преподавания языка с последнего десятилетия 20 века, так как многие ученые присоединились к обсуждению проведению аналитических исследований по этому вопросу. В этой работе мы попытались описать актуальность подхода, указав на то, что мы считаем положительным в этом подходе, и подчеркнув неадекватность некоторых предположений и выводов. Следует еще раз подчеркнуть, что практическиориентированный подход есть эффективной педагогической технологией преподавания и обучения. Принимая во внимание степень значимости компетенции по иностранному языку для студентов университета сегодня, мы выделили основные цели исследования, в частности: первая часть статьи была посвящена выяснению сущности такого педагогического явления, как «задачи», а также представила теоретический обзор практико-ориентированного подхода; затем вторая часть статьи основывалась на описании наиболее распространенных преимуществ и недостатков подхода; третья часть содержала описание этапов успешной учебной деятельности на основе задач (предыдущее задание; цикл задач; фокус на языке; соответствующее домашнее задание), а четвертая часть касалась раскрытия типов задач практико-ориентированного подхода (информационное расхождение, деятельность в раздумьях, недостатки в мыслях, поездка, деловой миксер, отдел туризма). Таким образом, в ходе исследования мы проиллюстрировали, что многочисленные преимущества практико-ориентированного подхода касаются: общение в реальной жизни в противовес языковому анализу; студентов и их потребностей, их возможности использовать языковые ресурсы в аутентичных коммуникативных ситуациях; поощрения самостоятельности студентов. Благодаря этому тидходу студенты могут анализировать то, что они знают, не знают или частично знают и нуждаются в совершенствовании; они мотивированы изучать язык. Таким образом они берут на себя ответственность за свой прогресс в изучении языка. Также было показано, что учителя могут использовать этот подход в смешанных классах, где и слабые, и сильные ученики могут успешно выполнять задачи по своему языкового уровня, с разной точностью в одной и той же ситуации общения и выяснять свои индивидуальные потребности. Еще одним результатом исследования является то, что студенты охватывают широкий спектр
\end{abstract}


языка, так как они не ограничиваются требованиями учебных программ к определенной лексике, грамматике или структур. Было рекомендовано использовать сочетание практико-ориентированного и традиционного подходов к изучению английского языка, чтобы достичь максимальной эффективности учебного процесса.

Ключевые слова: преподавания языка, методы, методика, коммуникативное мастерство, задачи, практикоориентированный подход, преимущества и недостатки, этапы, изучение языка.

\section{Introduction}

Problem Statement. Changes and shifts in language teaching have been present throughout the history of this discipline. At the basis of this apparently unending uncertainty about the efficiency of methods at specific historical moments there is also a permanent search and striving to find better ways of teaching and learning languages, which implies acknowledging dissatisfaction with ongoing methods and procedures. In the second half of the 20th century those changes in methodology were more frequent and pressing for teachers and learners. The need for communication among people of different cultures and languages. triggered by travelling and globalization, puts pressure on people to learn languages more quickly and efficiently.

Learning a new system of communication is also substantially different from what it used to be in previous centuries: we have more need to communicate orally (not only in writing and reading) and we cannot wait for years before we engage in real communication. This urgency to learn languages is felt everywhere within society al1 over the world. The search for new and more efficient methods is a consequence of our social organization and the requirements for fluid communication [1].

Latest Researches and Publications Review. Methodological changes follow each other within short periods of time. Even though the majority of educational innovations end in failure (Adams, R. and Chen D.) positive effects can be expected from most of them. But it is true that new methods do not appear al1 of a sudden or disconnected from the world into which they are born. They overlap for some time with current methodological practices. This 'incubation' period is a real test for new ideas: some of them pass the test, others do not. Many discussions, arguments and counterarguments are exhibited in the process. But sometimes what was considered a decisive gain against existing practices at a given moment, proved to be wrong a few years later, and a new theory or method replaced it in its turn. Once more? Where will the end lie. if there is to be one? The methods which prevail are usually those that are best suited to the challenges, demands and needs of the time $[1,2]$.

In other writings Sánchez have outlined two main trends in language teaching methodology: the 'grammatical' and the 'conversational' approach. Both approaches have been permanently in tension with each other and are representative of a dichotomy that seems to reappear again and again in different ways and formats: written vs. oral language; learning grammar vs. learning how to speak; and formal vs. informal language use. In the last part of the 20th Century the dichotomy focus on form vs. focus on content, teaching and learning language for accuracy vs. teaching and learning language for meaning developed as the new paradigm. Emphasis on one or the other end of the scale tends to be cyclical, so that if form. structure and accuracy prevailed in the sixties and seventies, meaning and communicative potential gained momentum in the eighties and aftenvards [1,3].

The emergence of the task-based approach is connected to what became known as the "Bangalore Project", according to the Prabhu, and was initiated in 1979 and completed in 1984. The word 'task' is often used here to refer to the special kind of activities carried on in the classroom. Such activities are characterized. among other features, by the emphasis put on meaning and the importance assigned to the process of doing things (how) vs. the prevailing role given to content (nzhut) in the teaching practice of that decade. The purpose of the project is to investigate new ways of teaching which sprang from a strongly felt pedagogic intuition, arising from experience generally but made concrete in the course of professional debate in India. This was that the development of competence in second language requires no systematization of language inputs or maximization of planned practice, but rather the creation of conditions in which learners engage in an effort to cope with communication [1, 3, 4]

Vygotsky thinks of language as a social event, a shared social activity through which individuals develop their personality within a community. In his view, language is not the result of 'isolated' learning; it requires a social basis. And linguistic ability is built inside our mind to communicate with the outside world. Children enhance their own personality as 'different' human beings precisely through contrast and interaction with their 
environment, and particularly with other human beings around them. In fact, Vygotsky considers that thought, as separate from language, takes root when interaction gives way to or turns into monologue. Through monologues children communicate with themselves, and they do that with words or sentences that might be difficult or impossible for others to understand [1].

The functional nature of language is highlighted by Firthian and Hallidayan linguistics. And it is through the work of Wilkins that this functional dimension is incorporated into methodological issues on language teaching $[5,11]$.

Wilkins does it by contrasting synthetic and analytic syllabuses. He describes synthetic language teaching as a strategy in which the different parts of the language are taught separately and step-by-step so that acquisition is a process of gradual accumulation of the parts until the whole structure of the language has been built up $[1,5,6]$

The situation is less satisfactory if we approach the teaching scene from a 'communicative' perspective. In this view, it is said that in the process of language acquisition the role of the learner is central and decisive. "Acquisition" as opposed to «learning» - is the true goal in language learning, but it takes place only if knowledge (language) is integrated by the individual into his own set of values and idiosyncrasy and if a linguistic system is built. «Learning» alone, according Krashen is not enough. The principle taken for granted in synthetic approaches, "what is taught = what is (or ought to be) learn", according Prabhu, cannot be accepted any more, since it comes from outside (external syllabus) or is imposed on the learner (by the teacher). Under those circumstances, «acquisition» will be hindered, or at least not favored. This is a job that only the learner can do; he must be «invited to collaborate in this purpose, assuring this goal by himself. As Long and Crookes put it, «language learning is more a psycholinguistic than a linguistic process». [1, 2, 3, 4].

The Aim of Research. Having conducted the theoretical analysis, we have taken into consideration the rate of the foreign language competence importance for modern university learners and identified the main purposes of the survey that are follows: the first part of the paper is dedicated to figuring out real world tasks and classroom tasks as well as presents theoretical overview of task-based approach; then the second part of the paper is grounded on the description of the most common advantages and disadvantages of the taskbased approach; the third part provides the steps for a successful task-based teaching activity and the fourth part is concerned with the reveal of types of assignments that are based on task-based teaching.

\section{Materials and Methods}

This study was conducted in the largest tertiary education institution in Ukraine, on the Faculty of International Relations with students on specialty "International Relations" which among other programs provides well-acknowledged internationally accredited higher education in the area of international relations. The purpose of the research is to study contemporary educational approaches of teaching English in order to increase students' knowledge, skills and abilities of their professional English language necessary for work in global business and determine opportunities for syllabus development on the basis of created practical taskbased section.

We offer one example, such as follows: Van den Branden defines task-based language learning as "an approach to language education in which students are given functional tasks that invite them to focus primarily on meaning exchange and to use language for real-world, non-linguistic purposes". In other words, TBL refers to an approach to teaching and learning which views the completion of meaningful tasks through authentic communication as an effective way to improve language proficiency in the natural, practical, and functional use. Task-based language learning and teaching give students something real to do using the language they are learning. Such tasks can include visiting a doctor, planning a tour, conducting an interview. Assessment is primarily based on task outcome rather than on accuracy of prescribed language forms, therefore there is no prior focus on language. This makes TBLT especially popular for developing target language fluency and student confidence (Fig. 1) [11].

The methodology of Task Based Learning (TBL) was first propounded and popularised by N. Prabhu (2012), who initiated practices of Task Based Learning (TBL), Task Based Language Teaching (TBLT) and Task Based Instructions (TBI) with major focus on the learning needs of Indian students with diverse sociolinguistic-cultural backgrounds. This methodology insists that students learn more of a language not when they are engaged in structural and/or grammatical forms of the target language; which means that, according to the 
principles of the TBL, students should be engaged in task based activities that enable them to acquire ESL/EFL in a better and friendly manner. Like the CLT, the focus of the TBL shifts from fixed grammatical structures of a language to planned lessons and Task Based Activities wherein learners are required to perform. The key principle of the TBL is, therefore, learning through performance. This approach involves students" engagement in a series of activities culminating in successful completion of tasks.

TASK BASED LEARNING

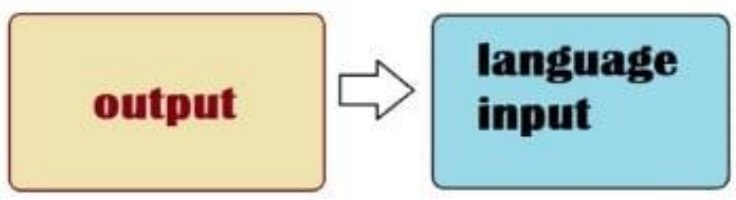

Fig. 1. Task Based Learning (TBL)

This method also emphasizes use of authentic, real world language actually practiced by competent users, native or non-native. It is worth noting that this method takes into consideration students" exposure to the real world and their knowledge of the same. Students" acquaintances with the real world are exploited to form lesson plans and task based activities to provide situational practice to them so that they can learn to reuse the language they have seen being used in the world around them. In this sense, the TBL also includes learners" skills deduction and individual analysis in terms of their own exposure to and knowledge of the target language actually practiced by competent users. Like the CLT, the TBL, two, provides motivation for adopting communicative skills while learning ESL/EFL. The point of similarity between the CLT and the TBL is an overt emphasis on communicative fluency rather than linguistic/structural/ grammatical accuracy. It is for this reason that the TBL advocates language learning through natural contextualization of the content used for language teaching. Such an emphasis calls for selection and adoption of teaching and learning material from authentic sources $[5,8,9,10]$.

\section{Results}

The initial step of our investigation is related to tasks description. First of all, tasks in everyday life are to be found everywhere. Tasks surround us from early in the morning till late at night. Washing our face is a task, as is preparing breakfast, going to work by car. preparing a lesson, buying the newspaper. Tasks pervade our lives, so much so that there is hardly an activity that cannot be called a task. When applied linguists and methodologists began using that word, they obviously relied in one way or another on the basic meaning it had in usual, plain speech. It is obvious that applied linguists were taking advantage of the semantic field covered by "task", but at the same time they consciously or not used the word restricting and adapting its meaning to concepts common to the field of language teaching-learning.

The «restricted» (pedagogical) or «unrestricted» (real world) semantic content assigned to "tasks" often leads to some confusion and misunderstandings. Regarding the features of real world tasks, the following set is suggested:

- they are goal-oriented or goal-guided activities ( performance is evaluated depending on the achievement or not of the goal);

- they consist most of the time of a sequence of steps, well differentiated but tightly connected among themselves, mutually conditioned by the logical sequence of the actions preceding and following each one of the steps ( failure to fulfill one of the steps can invalidate the outcome of the task);

- the process and procedures applied in the fulfillment of the task condition the effective and efficient achievement of the final goal, which is what really matters when we engage in a task, but procedures per se do not necessarily invalidate the attainment of the final goal;

- tools needed and procedures applied vary depending on the goals we aim at;

- $\quad$ the goal to be reached might be a problem to solve, but not necessarily; 
- while performing the task, efficiency is closely connected to the highest level of attention devoted to it, another one will probably be totally or partially abandoned;

- tasks in real life are fully holistic: in their realization the whole person is involved: mind and body, thought and action must be coordinated and work together. When coordination and cooperation is deficient, efficiency in task performance declines $[1,7,8,10]$.

Apart from the more traditional PPP (Present, Practice, Produce) approach there is a great number of different methods and approaches to teaching ESL. One of subcategories of communicative language teaching is TBL (task-based learning). Although it has been used for many years, its popularity has dramatically increased in recent years. This article presents an overview of this approach.

Scholars offer various interpretations and definitions of tasks selected for the Task Based Teaching. According to Rod Ellis, a "task" is a lesson plan that demands learners to study structures of language so as to arrive at an outcome which is to be estimated in terms of the delivery of content conveyed as per pre decided action plans. It, then, requires the learners to focus on the meaning of the content prescribed and the linguistic sense that they could make out of it.

David Nunan, an Australian linguists and author of the largest selling ELT textbook series "Go for It", defines a task as an action plan for the classroom which demands multiple activities on the part of the students who are supposed to derive comprehension, to manipulate as per the needs or to produce and/or interact with the same in the target language. He believes that the students of ESL/EFL have to translate their notional knowledge of grammatical structures into concrete interactive and communicative practices in the same language. For an ESL/EFL, classroom activities can be offered at pedagogical and linguistics levels. While linguistics tasks aim at handling structural forms, the pedagogical tasks deal with the meanings of the contents $[3,5]$.

The advantages of task-based learning can be summarized in the following statements.- The focus of the learning process moves from a teacher to students. Students themselves decide on the content of the task and they are free of language control. The role of the students is far from being one of the passive recipients of comprehensible input; students are now seen to take the leading role in their own learning, learners are autonomous to negotiate course content or to choose linguistic forms when performing a task. Teachers just address students' needs and interests by becoming facilitators:

- Task-based learning can bring teaching from abstract knowledge to real world application, a natural context.

- Task-based learning promotes real communication or the exchange of meanings rather than linguistic forms.

- Task-based learning gives the student a different way of understanding language as a tool instead of as a specific goal.

- Task-based learning is a strong communicative approach where students spend a lot of time communicating.

- Task-based learning involves many different skills and knowledge.

- Task-based learning brings a variety to your lessons and motivate students greatly $[6,7,9]$.

The disadvantages of TBL can be formulated as follows: TBL is potentially unpredictable as it is impossible to plan $100 \%$ what language the students will use during the task, therefore the teacher should be very flexible; TBL is time-consuming, because doing a task might extend over longer periods of time, more than just one lesson. If you want your students to make a poster or a video, they will have to do after the lesson in their free time $[5,7,10,11]$.

Jane Willis, teacher at Aston University, suggests steps for a successful task-based teaching activity: the pre-task; task cycle; language focus; a relevant homework assignment.

Step \#1. Pre-task. In the pre-task, the teacher introduces the topic, gives instructions and presents what will be expected of the students in the task phase. Skehan distinguishes between the 'weak' and 'strong' versions of TBLT approach. In weak end version a model of the task is shown before the students do it, the teacher may help the students to recall some key vocabulary or grammatical constructions. Moreover, teachers may present a model of the task by doing it themselves or by presenting pictures, audios, or video demonstrating the task. This gives the students a clear model of what will be expected of them. In "strong" 
task-based learning lessons, learners are responsible for selecting the appropriate language for any given context themselves $[5,6]$.

Step \#2. Task cycle. According to Willis, the most important is to choose a meaningful task which is related to real world activities. It should provide an opportunity to exchange information with a focus on meaning and have a clear purpose (students know the outcome they are expected to produce). The students complete a task in pairs or groups. Then students plan how they are going to report it to the rest of the class or to other groups. They prepare a short oral or written report, it might be a short speech, a video or a poster. Students can also practice their speaking before reporting the task, therefore, they feel more confident. The teacher's role is typically limited to an observer, they monitor, observe and clear up any language questions students may have. As a report students give a presentation of the task, exchange written reports, compare results and so on. The teacher chooses the order of when students will present their reports and may give the students some quick feedback on the content $[4,5,8]$.

Step \#3. Language focus. The teacher attracts students' attention to some patterns, vocabulary, grammar that emerged during the report or gives input on the 'gap' between what language the students used and the language which would be more relevant in the task. They discuss and analyse the language. Then the teacher conducts practice of new language depending on the needs of the students. The students then do practice activities to increase their confidence and make a note of useful language [7, 9].

Step \#4. Give a relevant homework assignment. Unless the activity is the culmination of a unit, chapter or class, you will likely need to come up with an appropriate homework assignment and a logical follow-up to the activity just completed in class. This too can take a number of forms. You might want to ask your students to write an essay based on their in-class work. They might write a reflective piece, a self-critique about what they accomplished and learned. They might write an assessment of the others in their group, of the other groups or of the project as a useful learning mechanism. They might turn in their own version of the project, as they would have done it if they could have worked independently, explaining why they would have done things differently had they had the opportunity $[3,5,8]$.

In this part of our survey we are intended to give a view of types of tasks that are based on task-based teaching.

Task \#1. Information gap activities are those that involve the transfer of information from one person to another, from one form to another or from one place to another. For example, two students might have different schedules, but they want to find time to get together to have tea. They need to get relevant information from each other to determine when they are both free, as well as when the available times coincide with when a tea house is open. This type of activity allows students to request information, ask for clarification and negotiate both meaning, particularly when misunderstandings occur, and appropriate conclusions to the task [1].

Task \#2. Reasoning gap activities are those in which you ask your students to derive some information from that which you give them. They are required to comprehend and convey information, much as in an information gap activity, but the information that they are asked to convey is not exactly the same that they comprehend. They are asked to use reason and logic to decide what information to convey and what resolution to make for the problem at hand. For example, you might ask your students to make a decision between speed and cost or cost and quality, given a certain situation and various constraints [1,3].

Task \#3. Opinion gap activities are those that ask students to convey their own personal preferences, feelings or ideas about a particular situation. On a higher level, you might ask them to take part in a discussion or debate about a political or social issue. On a lower level, you might ask them to complete a story. In these types of activities, there is no right or wrong answer, and, therefore, there is no objective means by which to judge outcomes, outside of whether what the students do or say addresses the task at hand. You might require them to speak or write for a certain amount (words or time) and you might ask them to use certain constructions. Otherwise, assessment is subjective rather than objective $[1,5,6]$.

Task \#4. Road Trip. At the beginning of the class, teachers should ask each group what information they need from you in order to plan the perfect trip. This might include the number of days you wish to travel, your budget and what you like to do while on the road or in your free time. Once your students have this information, set them loose with their maps and give them time to plan! 
When they are done, teachers have them present their trip to the entire class. The class, as a whole, can now vote on which trip you are going to take! Of course, they should be able to explain why they made the choice that they made, especially if they chose a trip other than the one their group created for you.

Depending on the level of the students, there are a couple of homework options. If it is a lower-level class, they could write a short postcard home, telling some key points of one day of the trip. And if it is a more advanced level class, they could write two or three days' journal entries, similar to a postcard, but more detailed and, of course, using more language skills [10,11].

Task \#5. The Business Mixer. Unioversity students or professionals will have to learn how to talk at mixers, parties and business functions. This means that they will need to learn to talk using a combination of small talk and job talk. The activity "The Business Mixer" will prepare them for this by doing a simulation activity in the target language.

For this activity, teachers need to prepare in advance a number of cards that will tell students such data, as: the name of their company; the product they sell or represent; some basic information about the company they work for and what they are looking for.

Before starting, teachers should ensure that all students know what a mixer or networking activity is and what it entails and might also want to have them think up a few basic introductions and small talk questions before letting them converse with each other. Teachers might even want to demonstrate the activity, using a different set of cards, with one of the students.

In the activity itself, students will walk around the room introducing themselves and engaging in some small talk, before discussing what it is they do and what they are looking for in a business deal or partner. They should move from person to person until they have found the perfect match! If they find their match before everyone else, they can continue to engage in small talk with others until everyone has found their match.

At the end of the activity, they should return to their perfect pair, and each can explain why it is that they are the match for that person. For homework, as in real life, your students can follow up with a brief handwritten note or short email message thanking their partner for their time and reiterating their interesting in working together [10, 11].

Task \#6. Department of Tourism. Many students who are studying a second language are doing so because they are either living in the country where that language is spoken or they want to visit that country. We can make a task-based activity that will prepare them for the latter!

We are going to ask students to brainstorm what they remember seeing either in print or on TV when a travel destination is advertised, for example, what stuck out in their mind, what made them want to go there, if they went there, what did they do while they were there, did it meet their expectations).

Now teachers have them think of a place in a country where the target language is spoken that they might like to visit (for example, what is it about that place that draws them to it, what do they think of when they think of that place, food, museums, scenery).

Now teachers can create small groups. If they already have a sense that several students are interested in the same place, go ahead and group them together. It will save time and arguments. If not, then either the students are randomly divided or have grouped by themselves. Each small group should decide where they would like to travel, if that has not already been determined, and what they would use in a poster campaign to advertise that locale based on what they know about the place.

Because this activity requires gathering materials, the next step should be done outside of classunless, of course, it is a class for much younger learners or other students that cannot do much research outside of class. In this case, teachers should divide the class, give each group a location and provide them with possible materials to use. The students will then design their own poster campaigns, complete with words and images, which they will then bring to the next class and present to their classmates as part of a tourism initiative.

As with other activities here, the students can vote on the best poster campaign. Teachers can actually have several categories, including best use of visuals, best wording and most convincing-the one that gets the most students thinking, "I want to go there!" 
As a homework student may write a letter to their parents asking for permission to go to the winning locale over Spring Break, being sure to explain why they want to go there, what they will do there and how, of course, being there will help their language to improve! $[6,7,8]$

\section{Discussions}

On the grounds of the conducted research we are able to make a conclusion that modern findings in the frame of task-based approach have revealed the necessity to create and implement plenty of various tasks and assignment in order to reach the highest level of learners' foreign language communicative competence whereas the previous researches, which were outlined at the beginning of the paper, have testified that leafrners' language results mainly depend on either on their own monologues or personal percepting abilities.

To sum up, modern education is on the way of the conditions provision of active participation of students' language acquisition through their communicative involvement.

\section{Conclusion}

To generalize, in task-based teaching, the center of the learning process moves to the students themselves and allows them to come to the realization that language is a tool to tackle and resolve real-world problems. The process of task-based learning itself teaches important skills. Students learn how to ask questions, how to negotiate meaning and how to interact in and work within groups. Within this group work, they are able to observe different approaches to problem solving as well as to learn how others think and make decisions. These are all skills that our students will need in order to be successful in the real world, regardless of which language they use there.

It must be admitted that the task-based teaching faces most of the problems inherent in natural methods, particularly when applied to adult learners of a second language. The difference between real world tasks and pedagogical tasks is at the very center of the problem. The classroom environment cannot be equated to the real world environment, or at least not fully equated to it. In a parallel way, learning a language in a natural environment, particularly in the early stages of life, differs considerably from learning a language as an academic subject.

Moreover, the history of teaching languages offers a long list of methods to teach and learn languages. We are not suggesting in this paper that we should reject new proposals and novel ideas, but we strongly feel that what we urgently need is to do more research on the mechanisms of learning and accompany new proposals and methods with more experimental evidence before we bring them into the classroom. Abstract constructs may be well elaborated and their elements may also be logically intertwined, but something more than that is needed for them to work in practice. The task-based teaching approach adds useful elements and contributes to the communicative language teaching with valuable procedures.

In addition, task-based teaching provides students with the linguistic components they will need to accomplish these real-world tasks.

Future Investigations Prospects. To our mind, future scientific methodological investigations could be aimed at creating complex of activities for task-based learning for the professional discipline "Theory and Practice of Translation".

References
1. Sanchez, A. (2004). The Task-based Approach in Language Teaching. International Journal of English Studies (IJES), vol. 4 (I), 39 - 71. DOI: 10.6018/ijes.4.1.48051

2. Crookes, G., Gass, S. (1993). Tasks in a Pedagogical Confext. Clevedon: Multilingual Matters. Cambridge: Cambridge University Press.

3. Ellis, R. (2003). Task-based Language Learning and Teaching. Oxford: Oxford University Press.

4. An approach to teaching English: task-based learning. URL: https://skyteach.ru/2018/04/20/an-approach-to-teaching-englishtask-based-learning (accessed 10.03.2010).

5. Modern Approaches to English Language Teaching and Learning. URL: https://shodhganga.inflibnet.ac.in/bitstream/10603/136729/7/07_chapter-1.pdf (accessed 10.03.2010).

6. The Real World: Classroom Edition! 5 Task-based Language Teaching Activities to Simulate Key Situations. URL: https://www.fluentu.com/blog/educator/task-based-language-teaching-activities/ (accessed 10.03.2010).

7. Chapman, C., Freeman, L. (1996). Multiple Intelligence Centers and Projects. Arlington Heights, IL: Skylight Training and Publishing.

8. Harmer, J. (2007). The Practice of English Language Teaching. Harlow, England: Pearson Longman. 
9. Penny, U. (2012). A Course in English Language Teaching. Cambridge: Cambridge UP.

10. The Key Foreign Language Teaching Methodologies and How to Choose the Best for You. URL: https://www.fluentu.com/blog/educator/foreign-language-teaching-methodology (accessed 10.03.2010).

11. Nunan, D. (2004). Task-Based Language Teaching. Cambridge: Cambridge University Press.

12. Willis, D., Willis, J. (2007). Doing Task-Based Teaching. Oxford: Oxford University Press.

13. Petty, G. (2009). Teaching today. Practical guide. United Kingdom: Cheltenham.

14. Hadley, A. (1993). Teaching Language in Context. Boston: Heinle and Heinle Publishers.

15. Hewings, M. (2003). Business English: Research into Practice. London: Pearson Education Limited.

16. Dellar, H. (2010). Outcomes. UK: Cambridge University Press.

17. Jones, L. (1998). Welcome. English for Travel and Tourism Industry. London: Cambridge University Press.

18. Martin, J. (1993). Intercultural Communication Competence: a Review. Beverly Hills, CA: Sage.

19. Naroll, R., Cohen, R. (1970). A Handbook of Method in Cultural Psychology. New York: Natural History Press.

20. Peterson, P. (2010). International Encyclopedia of Education. UK: University of Sussex, Brighton.

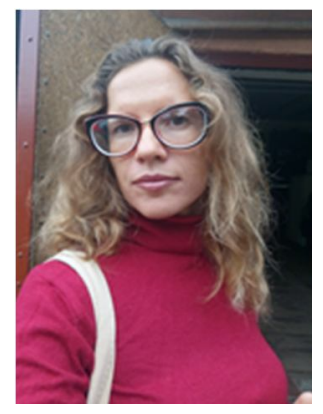

Василишина Наталія Максимівна,

Канд.пед.наук, доцент, доцент кафедри іноземних мов,

Національний авіаційний університет,

м.Київ, проспект Відрадний, 4.

Тел. (068)59-30-727. E-mail: filologyN@gmail.com

Vasylyshyna Nataliia Maksymivna,

Ph.D. in Pedagogics, Associate Professor, Associate Professor of Foreign Language Department

National aviation university, Kyiv, Ukraine,

Address. Otradnyy Av., 4

Тел. (068)59-30-727. E-mail: filologyN@gmail.com

ORCID: 0000-0002-0003-9998

Researcher ID: H-1189-2019

\section{Citation (APA):}

Vasylyshyna, N. (2020). Task-Based Approach in The Frame of Professional Preparation at Universities. Engineering and Educational Technologies, 8 (2), 8-17. doi: https://doi.org/10.30929/2307-9770.2020.08.02.01

\section{Цитування (ДСТУ 8302:2015):}

Василишина Н. М. Практико-зорієнтований підхід у процесі професійної підготовки в університетах / Інженерні та освітні технологіiі. 2020. Т. 8. № 2. С. 8-17. doi: https://doi.org/10.30929/2307-9770.2020.08.02.01

Обсяг статmі: сторінок-10 ; умовних друк. аркушів- 1,448. 